\title{
PENDIDIKAN KEARIFAN ETNIK DALAM MENGEMBANGKAN KARAKTER
}

\author{
Yusuf Tri Herlambang ${ }^{1}$
}

\begin{abstract}
ABSTRAK
Globalisasi selalu diikuti dengan adanya perkembangan ilmu pengetahuan dan teknologi. Hal ini telah memberi dampak signifikan dalam berbagai aspek konstelasi kehidupan, tak terkecuali dalam membangun paradigma masyarakat yang menjadikan kondisi ini sebagai sebuah sistem nilai kehidupan. Keadaan ini berpotensi untuk melahirkan marginalisasi budaya yang pada akhirnya akan mereduksi nilai budaya otentik dan hilangnya identitas bangsa. Selain dari itu keadaan ini telah membawa dampak buruk pada rendahnya karakter bangsa Indonesia, yang tidak mampu menjadikan nilai budaya sebagai perisai dalam menjalani kehidupan di tengah perubahan dan dinamika budaya yang berkembang. Pendidikan sebagai sektor esensial dalam kehidupan manusia yang merupakan syarat mutlak dalam membangun sebuah peradaban tinggi, hendaknya mampu menjalankan perannya dalam pengembangan mutu manusia Indonesia seutuhnya berdasarkan pendekatan budaya atau dalam latar kehidupan sosial budaya yang dinamis dan berpijak pada kearifan nilai budaya bangsa Indonesia, sehingga pendidikan dapat menjalankan fungsinya untuk mempertahankan dan menjaga sistem nilai budaya yang bertujuan untuk mengembangkan karakter insan-insan pendidikan Indonesia. Pendidikan berbasis kearifan Etnik merupakan pendidikan yang berorientasi pada upaya untuk menjaga kelestarian budaya dari reduksi akibat globalisasi serta menumbuhkan sikap positif dan konstruktif demi terciptanya integrasi sosial yang harmonis dalam kehidupan masyarakat. Selain dari itu, tujuan utama pendidikan kearifan Etnik adalah untuk membekali insaninsan pendidikan yang memiliki kemampuan adaptif, dan futuristik yang mengedepankan aspek intelektual, aspek moral dan sosial kultural, serta sebagai upaya dalam mewujudkan harapan masa depan bangsa Indonesia sebagai bangsa yang bermartabat dan memiliki identitas kepribadian.

Kata kunci: Globalisasi, Kearifan Etnik, Karakter
\end{abstract}

\section{A. PENDAHULUAN}

Abad 21 adalah sebuah tantangan yang merupakan keniscayaan dan mempengaruhi alur perubahan dunia, sehingga ideologi rentan tereduksi oleh transformasi kehidupan dalam multidimensional. Perubahan-perubahan tersebut mempengaruhi cara pandang manusia dalam melihat realitas kehidupan. Perubahan-perubahan yang secara terkait tersebut, secara dinamis dan progresif tidak dapat dihentikan, sehingga masyarakat akan semakin tenggelam dalam proses perkembangan globalisasi abad 21 yang semakin deras. Hal ini mengandung makna bahwa terdapat kecenderungan masyarakat yang akan mengadopsi budaya global sebagai sebuah sistem nilai yang akan dijadikan pijakan dalam berkehidupan, sehingga akan menimbulkan beberapa dampak

\footnotetext{
${ }^{1}$ Mahasiswa Program Studi Pedagogik SPs UPI Bandung
} 
negatif yang cukup besar bagi bangsa Indonesia yaitu lunturnya identitas bangsa. Hal ini sesuai dengan pendapat Tilaar (2002, hlm. 63) yang mengungkapkan bahwa mengadopsi budaya global tanpa dasar yang kuat dari kebudayaan sendiri berarti manusia Indonesia akan kehilangan identitasnya.

Keadaan ini merupakan ancaman terhadap budaya bangsa serta melemahnya kesadaran terhadap wawasan nusantara. Dengan kata lain arus globalisasi abad 21 saat ini memiliki potensi untuk melahirkan marginalisasi budaya yang pada akhirnya akan mereduksi nilai budaya otentik dan hilangnya identitas bangsa. Selain dari itu keadaan ini telah membawa dampak buruk pada rendahnya karakter bangsa Indonesia, yang tidak mampu menjadikan nilai budaya sebagai perisai dalam menjalani kehidupan di tengah perubahan dan dinamika budaya yang terus berkembang. Rendahnya karakter bangsa telah di ungkapkan oleh Kemendiknas (2010, hlm. 2) yang mengakui bahwa telah terjadi dekadensi moral di kalangan pelajar dan mahasiswa. Perilaku menabrak etika, moral dan hukum dari yang ringan sampai yang berat masih kerap diperlihatkan oleh pelajar dan mahasiswa. Keadaan ini merupakan cerminan dari kehidupan yang tidak berkarakter kuat untuk menuju bangsa yang berperadaban maju. Hal ini berbanding terbalik dengan yang telah diamanatkan dalam UU No. 20 Tahun 2003.

Pendidikan sebagai sektor esensial dalam kehidupan manusia, khususnya bangsa Indonesia yang merupakan syarat mutlak dalam membangun sebuah peradaban tinggi, hendaknya mampu menjalankan peran dan fungsinya dalam pengembangan mutu sumber daya manusia (SDM) Indonesia yang memiliki kemampuan adaptif dan futuristik serta berkarakter berdasarkan pendekatan budaya. Keadaan ini penting dipahami pada pengembangan pendidikan dalam latar kehidupan sosial budaya yang dinamis dan berpijak pada kearifan nilai budaya bangsa Indonesia, sehingga pendidikan dapat menjalankan fungsinya untuk mempertahankan dan menjaga sistem nilai budaya yang bertujuan untuk mengembangkan karakter insan-insan pendidikan Indonesia. Namun, kenyataan yang ada pendidikan sebagai proses pembudayaan dalam upaya mengembangkan karakter, saat ini telah mengalami pendangkalan makna. Pendidikan dalam proses pembudayaan telah diartikan secara sempit sebagai sebuah proses intelektualisme yang menjadikan pendidikan sebagai sebuah proses pembudayaan yang hanya didasarkan pada upaya pembekalan pengetahuan pada unsur kebudayaan tertentu, dan telah mengabaikan unsur-unsur nilai kebudayaan lain sebagai hal yang fundamental. Selain itu pendidikan sebagai proses pembudayaan lebih diorientasikan pada hal yang bersifat estetis yang berkaitan dengan kesenian, seni pahat, seni tari, seni lukis, dsb. Sehingga menyikapi kondisi ini Tilaar (2002, hlm. 67) berpendapat bahwa pendidikan telah dicabik dari keberadaannya sebagai bagian yang terintegrasi dengan kebudayaannya.

Berkaitan dengan hal di atas, pendidikan dapat menjadi sebuah sarana dalam membangun peradaban yang didasarkan pada nilai-nilai kebudayaan bangsa Indonesia. Hal ini sejalan dengan pendapat Al Muchtar (2001, hlm. 296) yang mengungkapkan bahwa "Menempatkan pendidikan sebagai aspek kebudayaan serta mencari alternatif pemecahannya atas dasar berpikir analitik kebudayaan, merupakan suatu keharusan, sebagai jawaban atas tuntutan nilai intrinsik 
pendidikan itu sebagai bagian dari kebudayaan". Senada dengan itu, Mekagiansar (dalam Soedjatmiko, 1983, hlm. 53) berpendapat bahwa peranan pendidikan selain "Menjamin stabilitas dan validitas kultural, suatu persiapan untuk memberikan ruang pada kedambaan dasar manusia untuk mengubah melampaui dirinya sendiri". Selanjutnya "visi masa depan syarat fungsional untuk pertumbuhan dan kontinuitas sosial kultural".

Bertitik tolak pada penjelasan di atas, perlu adanya gagasan untuk melakukan reinterpretasi dan revitalisasi terhadap dunia pendidikan yang tidak tercerabut dari nilai-nilai kebudayaan bangsa Indonesia melalui sebuah program pendidikan berbasis kearifan etnik, sehingga pendidikan memiliki kekokohan logika internal, memiliki daya keterbukaan dan fleksibilitas dalam menerima sumbangan pemikiran dari logika eksternal. Namun demikian, dalam kenyataan tidak sedikit lembaga Pendidikan di setiap jenjang, khususnya Pendidikan Sekolah dasar yang mengabaikan bahkan meninggalkan nilai-nilai budaya lokal. Hal ini merupakan salah satu penyebab semakin terduksinya budaya lokal pada kehidupan generasi yang akan datang.

Berdasarkan penjelasan di atas, pendidikan berbasis kearifan Etnik merupakan pendidikan yang berorientasi pada upaya untuk menjaga kelestarian budaya dari reduksi akibat globalisasi serta menumbuhkan sikap positif dan konstruktif demi terciptanya integrasi sosial yang harmonis dalam kehidupan masyarakat. Selain dari itu, tujuan utama pendidikan berbasis kearifan Etnik adalah untuk membekali insan-insan pendidikan yang memiliki kemampuan adaptif, dan futuristik yang mengedapankan aspek intelektual, dan aspek moral dan sosial kultural (berkarakter), serta sebagai upaya dalam mewujudkan harapan masa depan bangsa Indonesia sebagai bangsa yang bermartabat dan memiliki identitas kepribadian. Berdasarkan hal tersebut, maka dilakukanlah pengkajian yang bertujuan untuk memberikan pemahaman secara komprehensif melalui analisis implikatif pendidikan berbasis kearifan etnik dalam mengembangkan karakter.

\section{B. KONSEP PENDIDIKAN BERBASIS KEARIFAN ETNIK \\ 1. Hakikat Pendidikan Berbasis Kearifan Etnik}

Pendidikan Menurut John Dewey (dalam Muslich, 2011, hlm. 67) adalah proses pembentukan kecakapan fundamental secara intelektual dan emosional ke arah alam dan sesama manusia. Tujuan pendidikan dalam hal ini agar generasi muda sebagai penerus dapat menghayati, memahami, mengamalkan nilai-nilai atau norma-norma tersebut dengan cara mewariskan segala pengalaman, pengetahuan, kemampuan dan keterampilan yang melatar belakangi nilai-nilai dan norma-norma hidup dan kehidupan.

Berdasarkan pendapat di atas, pendidikan sebagai pranata sosial tidak hanya berfungsi untuk melakukan transformasi yaitu perubahan dan pembaharuan masyarakat beserta nilai-nilai budayanya, melainkan juga berfungsi dalam melakukan konservasi, yaitu untuk mentransmisikan/ mewariskan atau melestarikan nilai-nilai budaya masyarakat dan atau mempertahankan kelangsungan eksistensi masyarakat. Hal ini sejalan dengan pendapat Zhang \& Cheng (dalam Lutan, 2001, hlm. 32) yang mengungkapkan bahwa nilai adalah inti 
dari sebuah sistem budaya, dan inti budaya terdiri atas serangkaian konsep pada umumnya dan sistem nilai pada khususnya. Selain dari itu pendidikan sebagai pranata sosial yang melakukan fungsi konservatif di dasari atas pertimbangan bahwa di dalam masyarakat terdapat nilai-nilai, pengetahuan, dan perilakuperilaku berpola yang masih relevan dan dipandang baik yang harus tetap dilestarikan. Hal ini sejalan dengan pendapat (Alwasilah, et al, 2009, hlm. 16) yang mengungkapkan bahwa pendidikan dipandang bermakna deliberatif, artinya setiap masyarakat berusaha mentransmisikan dan mengabadikan gagasan kehidupan yang baik, yang berasal dari kepercayaan masyarakat yang fundamental yang berkenaan dengan hakikat dunia, pengetahuan, dan nilai-nilai. Dalam kaitannya, pendidikan sebagai pranata sosial yang memiliki fungsi konservatif berfokus pada sebuah tinjauan kearifan etnik yang merupakan bentuk revitalisasi atau menghidupkan kembali spirit kekayaan kultural yang pada gilirannya akan mewarnai pendidikan Indonesia dalam menemukan identitas dirinya.

Dalam kajian ini, penggunaan istilah kearifan etnik didasarkan pada pandangan objektif yang berupaya untuk membatasi adanya sebuah multi interpretasi terhadap pemaknaan istilah itu sendiri yang sarat akan nilai kebijakan secara partikular. Dalam hal ini istilah kearifan etnik digunakan untuk mengkhususkan sebuah objek kajian yang memiliki nilai-nilai kebijakan etnik tertentu. Namun, secara substansi istilah kearifan etnik memiliki makna sama dengan istilah kearifan lokal yang merupakan sebuah koleksi fakta, konsep, kepercayaan, dan persepsi masyarakat ihwal dunia sekitar. Singkatnya kearifan etnik atau kearifan lokal adalah proses bagaimana pengetahuan dihasilkan, disimpan, diterapkan, dikelola, dan diwariskan dari generasi ke generasi secara turun temurun. (Alwasilah, et al. 2009, hlm. 50). Jika ditinjau secara etimologi, kearifan lokal (local wisdom) terdiri dari dua kata: kearifan (wisdom) dan lokal (local). Selain dari itu, Kearifan lokal dalam bahasa asing sering dikonsepsikan sebagai kebijakan setempat (local wisdom), pengetahuan setempat (local knowledge) atau kecerdasan setempat (local genious). Secara umum maka local wisdom (kearifan setempat) dapat dipahami sebagai gagasan-gagasan setempat (local) yang bersifat bijaksana, penuh kearifan, bernilai baik, dan anjuran untuk kemuliaan manusia yang tertanam dan diikuti oleh anggota masyarakatnya. Dengan kata lain bahwa penguasaan atas kearifan lokal akan mengusung jiwa mereka semakin berbudi luhur.

Sibarani, (2012, hlm. 112) yang berpendapat bahwa Kearifan lokal adalah kebijaksanaan atau pengetahuan asli suatu masyarakat yang berasal dari nilai luhur tradisi budaya untuk mengatur tatanan kehidupan masyarakat. Dengan kata lain kearifan lokal lebih menekankan pada kebijaksanaan atau kearifan untuk menata kehidupan sosial yang berasal dari nilai budaya yang luhur. Lebih lanjut Sibarani menjelaskan pandangan kearifan lokal yang difokuskan pada nilai budaya yaitu suatu nilai budaya lokal yang dapat dimanfaatkan untuk mengatur tatanan kehidupan masyarakat secara arif atau bijaksana. Sejalan dengan Sibarani, Ridwan (2007, hlm. 2) berpendapat bahwa Kearifan lokal atau sering disebut local wisdom dapat dipahami sebagai usaha manusia dengan menggunakan akal budinya (kognisi) untuk bertindak dan bersikap terhadap sesuatu, objek, atau 
peristiwa yang terjadi dalam ruang tertentu. Lebih jelas Keraf (2010, hlm. 369) berpendapat bahwa kearifan lokal adalah semua bentuk pengetahuan, keyakinan, pemahaman atau wawasan serta adat kebiasaan atau etika yang menuntun perilaku manusia dalam kehidupan di dalam komunitas ekologis. Seluruh kearifan tradisional ini dihayati, dipraktikkan, diajarkan dan diwariskan secara berkesinambungan dari satu generasi ke generasi lain yang sekaligus membentuk pola perilaku manusia sehari-hari, baik terhadap sesama manusia maupun terhadap alam dan yang gaib. Terdapat beberapa ciri-ciri kearifan lokal atau kearifan etnik yaitu: (1) berdasarkan pengalaman; (2) teruji setelah digunakan berabad-abad; (3) dapat diadaptasi dengan kultur kini; (4) padu dalam praktek keseharian; (5) lazim dilakukan oleh individu atau masyarakat dan lembaga; (6) bersifat dinamis dan terus berubah, dan (7) sangat terkait dengan sistem kepercayaan. Pemberdayaan melalui adaptasi pengetahuan lokal ini, termasuk reinterpretasi nilai-nilai yang terkandung dalam sejumlah peribahasa, dengan kondisi kontemporer adalah strategi cerdas untuk memecahkan problem sosial karena dalam banyak hal problem sosial itu bersumber pada persoalan lokal juga. (Alwasilah, C \& et al, 2009, hlm. 51)

Berdasarkan pendapat di atas, maka kearifan etnik atau kearifan lokal dimaknai sebagai keunggulan budaya masyarakat yang lahir dari budaya masa lalu dan patut secara terus menerus dijadikan sebagai pegangan hidup. Meskipun bernilai lokal tetapi nilai yang terkandung di dalamnya dianggap sangat universal. Hal ini memberi pemahaman bahwa kearifan lokal tidak sekadar sebagai acuan tingkah laku seseorang, tetapi lebih jauh, yaitu mampu mendinamisasi kehidupan masyarakat yang penuh keadaban.

Secara substansial, kearifan etnik atau kearifan lokal merupakan sebuah nilai-nilai yang berisi unsur kecerdasan dan kreativitas yang diyakini kebenarannya dan menjadi acuan dalam perilaku sehari-hari pada suatu masyarakat dan menjadi karakteristik masyarakat tersebut. Oleh sebab itu, sangat beralasan jika kearifan lokal dikatakan sebagai sebuah entitas yang sangat menentukan harkat dan martabat manusia dalam komunitasnya untuk membangun peradaban masyarakat tertentu.

Berkaitan dengan hal di atas, maka dapat disimpulkan bahwa kearifan etnik/ kearifan lokal merupakan manifestasi kepribadian suatu masyarakat dari nilai-nilai kehidupan yang menjadi pedoman dalam menjalani kehidupan. Artinya identitas masyarakat tercermin dalam orientasi yang menunjukkan pandangan hidup serta sistem nilainya. Di dalam kearifan lokal tercakup berbagai mekanisme dalam menjalani kehidupan yang dituangkan dalam suatu tata sosial yang bersifat partikular. Hal tersebut didasarkan pada aspek kehidupan yang terdiri dari beberapa dimensi. Ife (2002, hlm. 101-102) berpendapat bahwa terdapat 5 dimensi kultural tentang kearifan lokal yaitu pengetahuan lokal, budaya lokal, keterampilan lokal, sumber daya lokal dan proses sosial lokal. Berdasarkan kelima dimensi di atas, dimensi kultural tersebut merupakan kecerdasan-kecerdasan lokal yang ditransformasikan ke dalam cipta, karya dan karsa, sehingga masyarakat dapat secara mandiri dalam berbagai iklim sosial yang berbeda-beda. 


\section{Orientasi Pendidikan Berbasis Kearifan Etnik}

Pendidikan adalah sebuah proses pembudayaan, dengan demikian memisahkan pendidikan dari kebudayaan berarti mengkhianati keberadaan proses pendidikan sebagai proses pembudayaan. Hal ini sejalan dengan pendapat $\mathrm{Ki}$ Hadjar Dewantara (dalam Tilaar, 2002, hlm. 68) bahwa kebudayaan tidak dapat dipisahkan dari pendidikan bahkan kebudayaan merupakan alas atau dasar pendidikan. Agar pendidikan dapat merealisasikan cita-citanya, maka diperlukan sebuah konsep atau kerangka pendidikan yang mampu mengembangkan segenap potensi yang dimiliki oleh manusia. Oleh sebab itu pendidikan berbasis kearifan etnik berusaha mengetahui kekuatan-kekuatan yang membuat manusia melakukan sesuatu dengan potensi yang dimilikinya, merupakan upaya yang bijaksana untuk mengurangi kekhawatiran hilangnya jati diri, kepekaan sosial, dan tumpul kecerdasan sosialnya. Konsep ini diharapkan dapat menggali berbagai keunikan kearifan etnik beserta nilai-nilai budaya bangsa yang terkandung di dalamnya.

Berdasarkan penjelasan di atas, Pendidikan berbasis kearifan etnik merupakan pendidikan yang didasarkan pada pendekatan antropologis, sosiologis dan kultural. Hal ini berdasarkan pertimbangan bahwa proses pendidikan tidak dapat dilakukan secara seragam melainkan harus memahami konteks kultural dari hasil identifikasi pada khazanah budaya lokal sebagai pranata sosial yang secara fungsional berperan sebagai seperangkat teknik pemecahan masalah yang diwariskan sebagai kebudayaan dari satu generasi ke generasi berikutnya. Berkaitan dengan pentingnya budaya lokal atau kearifan Etnik, Tilaar (2004) menjelaskan "pengenalan terhadap budaya lokal kepada peserta didik sangat diperlukan sehingga mereka dapat menghayati budayanya dan dirinya sendiri". Dengan demikian, lembaga pendidikan sebagai pusat budaya juga merupakan pusat dialog dan komunikasi antarwarga lokal sehingga dapat bertukar pikiran, kerja sama, saling menghargai dan memandang perbedaan sebagai potensi yang berguna bagi berbagai pihak.

\section{Implementasi Pendidikan Berbasis Kearifan Etnik}

Implementasi pendidikan berbasis kearifan etnik merupakan sebuah proses Internalisasi nilai-nilai budaya yang dilakukan secara terencana dan terprogram yang diorientasikan pada kesadaran akan pentingnya budaya lokal sebagai identitas diri yang harus dijaga, dilestarikan dan dikembangkan serta dijadikan pedoman dalam kehidupan.

Dalam kenyataannya, budaya lokal seakan mengalami keterasingan pada posisinya dalam dinamika kehidupan yang berformat global. Hal ini disebabkan karena paradigma masyarakat yang menganggap bahwa budaya lokal dan segala yang berada didalamnya, bukanlah menjadi bagian dari kehidupan modern. Oleh sebab itu tidak berlebihan jika dalam kondisi ini budaya lokal mengalami sebuah keterasingan (alienasi) yang sebenarnya menjadi bagian tak terpisahkan di dalam kehidupan.

Berdasarkan tinjauan di atas internalisasi nilai-nilai kearifan etnik dapat dilakukan melalui pembelajaran yang bersumber pada nilai-nilai kearifan etnik dengan pendekatan dan strategi pembelajaran yang lebih menekankan pada kontekstualisasi pengetahuan peserta didik, sehingga dapat memberikan 
pemahaman makna dari nilai-nilai kearifan etnik tersebut. Selain dari itu pembelajaran yang didasarkan pada nilai kearifan etnik dapat menjadi pedoman dalam mengembangkan karakter, karena kearifan etnik merupakan upaya dalam membangun identitas bangsa, dan sebagai filter dari pengaruh budaya asing. Namun demikian proses Internalisasi tersebut sebenarnya tidak hanya tumbuh berdasarkan kesadaran dalam kehidupan sekolah, melainkan harus ditunjang dalam lingkungan pendidikan lainnya, baik itu dalam lingkungan keluarga maupun lingkungan masyarakat. Adapun strategi dalam Implementasi pendidikan dalam proses internalisasi kearifan Etnik dapat dilaksanakan dalam beberapa lingkungan pendidikan yang mampu menunjang proses internalisasi nilai-nilai kearifan etnik, baik itu dalam lingkungan sekolah, proses pembelajaran, kegiatan ekstrakulikuler dan kegiatan keseharian peserta didik, sehingga diharapkan proses Internalisasi dapat berjalan secara optimal dan sesuai dengan apa yang diharapkan. Dalam kaitannya, Internalisasi nilai-nilai kearifan etnik dalam lingkungan pendidikan perlu didasari dari kesadaran warga sekolah, khususnya guru dan kepala sekolah yang seyogianya mampu membangun lingkungan pendidikan bernuansa kearifan etnik. Hal ini mengandung makna bahwa lingkungan pendidikan harus terdapat unsur-unsur kebudayaan yang akan dipertahankan. Hal ini dapat dilakukan dengan beberapa starategi dengan menjadikan kegiatan pendidikan sebagai proses pembudayaan, yaitu dengan kegiatan pembelajaran yang mengintegrasikan nilai kearifan etnik dalam membentuk pengetahuan, dan kesadaran budaya, baik itu melalui mata pelajaran, lintas mata pelajaran maupun melalui muatan etnik. Selain dari itu proses Internalisasi nilai-nilai kearifan etnik dapat dilakukan dalam beberapa kegiatan ekstrakulikuler siswa yang dianggap sebagai sarana strategis dalam mengembangkan keterampilan budaya. Kegiatan-kegiatan tersebut dapat melalui ekstrakulikuler dalam bidang seni budaya. Namun dalam pelaksanaannya, proses Internalisasi nilai-nilai kearifan etnik tidak akan mampu berjalan secara optimal, jika tidak dibangun sebuah sinergi antar elemen, khususnya sekolah, keluarga dan masyarakat. Perlu kiranya lingkungan keluarga dan lingkungan masyarakat sebagai lingkungan kehidupan siswa ikut serta dalam menjalankan perannya untuk membentuk pengetahuan, dan kesadaran budaya sebagai hal yang fundamental. Sehingga dalam hal ini proses Internalisasi nilai kearifan etnik dapat berjalan secara optimal dan sesuai dengan apa yang diharapkan.

\section{KONSEP PENDIDIKAN KARAKTER}

\section{Pengertian Pendidikan Karakter}

Dalam Kamus Besar Bahasa Indonesia (Depdiknas, 2008) merupakan sifatsifat kejiwaan, akhlak atau budi pekerti yang membedakan seseorang dari yang lain. Soedarsono (2008, hlm. 16) mengungkapkan bahwa Karakter merupakan nilai-nilai yang terpateri dalam diri kita melalui pendidikan, pengalaman, percobaan, pengorbanan, dan pengaruh lingkungan, dipadukan dengan nilai-nilai dari dalam diri manusia menjadi semacam nilai intrinsik yang mewujud dalam suatu sistem daya juang melandasi pemikiran, sikap dan perilaku kita. Berdasarkan penjelasan di atas, terdapat makna tersirat mengenai karakter yang tidak hanya diartikan sebagai bentuk integrasi dari nilai intrinsik dan ekstrinsik 
yang dipadukan dan terejawantahkan dalam bentuk pemikiran, sikap dan perilakunya dalam kehidupan, melainkan lebih jauh karakter dapat dimaknai sebagai sesuatu hal yang melandasi setiap kegiatan manusia dalam menjalankan perannya dalam kehidupan, baik perannya dalam kehidupan bermasyarakat, berbangsa dan bernegara. Hal ini sejalan dengan pendapat Battistich (dalam Musfiroh, 2008, hlm. 27) yang berpendapat bahwa karakter mengacu kepada serangkaian sikap (attitude), Perilaku (behaviour), Motivasi (motivations), dan keterampilan (skills). Selain dari itu, hal tersebut dipertegas oleh pendapat Suyanto (dalam Muslich, 2011, hlm. 70) yang mengungkapkan bahwa "karakter adalah cara berpikir dan berperilaku yang menjadi ciri khas dari setiap individu untuk hidup dan bekerjasama, baik dalam lingkup keluarga, masyarakat, bangsa dan Negara".

Dari pendapat para ahli mengenai karakter di atas, dapat ditarik kesimpulan, bahwa karakter dapat diartikan sebagai bentuk refleksi nilai intrinsik dalam diri, baik itu pikiran, perkataan maupun perbuatan yang merupakan hasil dari internalisasi nilai-nilai kebajikan yang dijadikan sebagai landasan dalam menjalani kehidupan, atau merupakan suatu bentuk pengejawantahan dari internalisasi nilai-nilai kebajikan dalam kehidupan.

Sejalan itu pula, Lickona (1992, hlm. 22) berpendapat bahwa karakter merupakan sifat alami seseorang dalam merespons situasi secara bermoral. Sifat alami itu dimanifestasikan dalam tindakan nyata melalui tingkah laku yang baik, jujur, bertanggung jawab, menghormati orang lain dan karakter mulai lainnya. Lebih lanjut, Lickona berpendapat bahwa pendidikan karakter yang baik meliputi tiga komponen, yaitu Moral Knowing, Moral feeling dan Moral Action. Oleh sebab itu Pendidikan sebaiknya dimaknai sebagai proses dalam membangun kesadaran, menumbuhkan kepekaan, niat, wawasan, pengetahuan, keyakinan, sikap dan pembentukkan kebiasaan yang baik.

Konsep mengenai nilai dan karakter bangsa bukanlah sesuatu yang dihasilkan berdasarkan adopsi nilai filosofis dari luar, melainkan berpijak pada sebuah filosofis bangsa Indonesia berdasarkan nilai Pancasila. Sehingga dalam hal ini, karakter bangsa diorientasikan pada upaya penghayatan nilai-nilai Pancasila yang kemudian mampu direfleksikan oleh setiap warga Negara/ masyarakat di dalam kehidupannya. Namun demikian, nilai dan karakter bangsa tersebut merupakan akumulasi dari nilai dan karakter lokal masyarakat, sehingga kearifan lokal atau kearifan etnik merupakan hal substansial yang membutuhkan pengkajian mendalam, karena akan berkenaan dengan upaya pembentukan karakter bangsa.

\section{Prinsip-Prinsip Pendidikan Karakter}

Dalam pelaksanaan pendidikan karakter, terdapat prinsip-prinsip dasar dalam mengembangkan pendidikan karakter. Kemendiknas (2010, hlm. 10-13) mengemukakan prinsip-prinsip pengembangan pendidikan karakter adalah (1) Berkelanjutan; (2) Melalui semua mata pelajaran, pengembangan diri, dan budaya satuan pendidikan; (3) Nilai tidak diajarkan tapi dikembangkan melalui proses belajar (value is neither cought nor taught, it is learned), (4) Proses pendidikan dilakukan peserta didik secara aktif dan menyenangkan. 
Berkaitan hal di atas, beberapa prinsip tersebut merupakan hal yang fundamental dalam pelaksanaan proses kegiatan pembelajaran yang berorientasi pada upaya pengembangan karakter peserta didik. Sehingga sudah sebaiknya pembelajaran didasarkan pada prinsip-prinsip di atas yang diyakini efektif dalam upaya mengembangkan pendidikan karakter.

\section{Tujuan Pendidikan Karakter}

Pendidikan karakter merupakan pendidikan yang bertujuan dalam mengembangkan potensi dan meningkatkan kompetensi yang secara utuh dapat membekali peserta didik untuk menjadi warga masyarakat yang ideal, yaitu warga masyarakat bermartabat, yang mampu merefleksikan nilai-nilai Pancasila dalam kehidupannya. Selain itu, Asmani (2011, hlm. 43) berpendapat bahwa pendidikan karakter bertujuan untuk meningkatkan mutu proses dan hasil pendidikan yang mengarah pada pembentukkan karakter dan akhlak mulia peserta didik secara utuh, terpadu dan seimbang, sesuai dengan standar kompetensi lulusan pada setiap satuan pendidikan. Senada dengan Asmani, secara komprehensif Amin (2011, hlm.37) mengungkapkan bahwa fungsi pendidikan karakter adalah untuk menumbuhkan kemampuan dasar peserta didik agar berpikir cerdas, berperilaku yang berakhlak, bermoral dan berbuat sesuatu yang baik, yang bermanfaat bagi diri sendiri, keluarga dan masyarakat (domain kognitif, afektif, psikomotorik), membangun kehidupan bangsa yang multikultural, membangun peradaban bangsa yang cerdas, berbudaya luhur, berkontribusi terhadap pengembangan hidup umat manusia, membangun sikap warga Negara yang cinta damai, kreatif, mandiri, maupun hidup berdampingan dengan bangsa lain. Hal tersebut sejalan dengan apa yang telah tertuang dalam Undang-Undang Nomor 20 Tahun 2003 tentang sistem pendidikan nasional yang dirumuskan dalam pasal 3 bahwa:

"Pendidikan Nasional bertujuan untuk berkembangnya potensi peseta didik agar menjadi manusia beriman dan bertakwa kepada Tuhan Yang Maha Esa, berakhlak mulia, sehat, berilmu, cakap, kreatif, mandiri, dan menjadi warga Negara yang demokratis serta bertanggung jawab".

Berdasarkan penjelasan tersebut dirumuskan tujuan pendidikan karakter secara umum adalah untuk membangun dan mengembangkan karakter peserta didik pada setiap jalur, jenis, dan jenjang pendidikan agar dapat menghayati dan mengamalkan nilai-nilai luhur menurut ajaran agama dan nilai-nilai luhur dari setiap butir sila dari Pancasila. Secara khusus bertujuan mengembangkan potensi anak didik agar berhati baik, berpikiran baik, berkelakuan baik, memiliki sikap percaya diri, bangga pada, bangsa dan Negara, dan mencintai sesama umat manusia. Dengan kata lain pendidikan karakter memiliki tujuan untuk memfasilitasi penguatan dan pengembangan nilai-nilai tertentu sehingga terwujud dalam perilaku anak.

\section{Implementasi Pendidikan Karakter}

Dalam implementasi Pendidikan karakter, pada umumnya menekankan pada keteladanan, penciptaan lingkungan dan pembiasaan melalui berbagai tugas keilmuan dan kegiatan kondusif. Dengan demikian, apa yang dilihat, didengar, dirasakan dan dikerjakan oleh peserta didik dapat membentuk karakter mereka. Selain menjadikan keteladanan dan pembiasaan sebagai metode pendidikan 
utama, penciptaan iklim dan budaya serta lingkungan yang kondusif juga sangat penting, dan turut membentuk karakter peserta didik. Wibowo (2012, hlm. 45) berpendapat bahwa terdapat beberapa syarat utama dalam keberhasilan implementasi pendidikan karakter, di antaranya: (1) teladan dari guru, karyawan, pimpinan sekolah dan para pemangku kebijakan di sekolah; (2) pendidikan karakter dilakukan secara konsisten dan secara terus-menerus; dan (3) penanaman nilai-nilai karakter yang utama.

Pendidikan Karakter dapat di implementasikan dengan berbagai strategi dan pendekatan melalui berbagai kegiatan yang dilakukan secara intrakurikuler maupun ekstrakulikuler. Strategi dalam pendidikan karakter dapat dilakukan melalui sikap-sikap keteladanan, penanaman kedisiplinan, pembiasaan, menciptakan suasana yang kondusif, integrasi dan internalisasi. Selain dari itu, implementasi pendidikan karakter seyogianya dilakukan berdasarkan pendekatan dan strategi tertentu dengan memperhatikan karakteristik dan latar belakang budaya siswa yang heterogen dan kemudian dikembangkan dengan sebuah model eklektik yang diyakini efektif dalam implementasi pendidikan karakter.

\section{PENUTUP}

Pendidikan dan kebudayaan sejatinya merupakan dua hal yang bersifat komplementer dan terintegrasi dalam satu unit bagian yang mengikat, sehingga pendidikan dapat menjadi sebuah sarana dalam membangun peradaban yang didasarkan pada nilai-nilai kebudayaan bangsa Indonesia. Hal tersebut penting dipahami karena Pendidikan sebagai sektor esensial dalam kehidupan manusia, khususnya bangsa Indonesia yang merupakan syarat mutlak dalam membangun sebuah peradaban tinggi, hendaknya mampu menjalankan peran dan fungsinya dalam mempertahankan dan menjaga sistem nilai budaya yang bertujuan untuk mengembangkan Manusia Indonesia seutuhnya yang memiliki kemampuan adaptif, dan futuristik yang mengedepankan aspek intelektual, aspek moral dan sosial kultural berdasarkan pendekatan budaya atau dalam latar kehidupan sosial budaya yang dinamis dan berpijak pada kearifan nilai budaya bangsa Indonesia.

\section{DAFTAR PUSTAKA}

Al Muchtar, S. (2001). Pendidikan \& Masalah Sosial Budaya. Bandung: Gelar Pustaka Mandiri.

Ali, M. (2014). Pendidikan dan Pembangunan Nasional: Menuju Bangsa Indonesia yang Mandiri dan Berdaya Saing Tinggi. Bandung: Imtima.

Alwasilah, A. C, et al. (2009). Etnopedagogi: Landasan praktek pendidikan dan pendidikan guru. Bandung: Kiblat Buku Utama.

Amin. (2011). Pendidikan karakter Anak Bangsa. Jakarta: Baduose Media.

Asmani. (2011). Pendidikan Karakter di Sekolah. Yogyakarta: Diva Press.

Ife, J. (2002). Community Development, Community-Based Alternatives in an. Age Of Globalisations. Australia: Longman Pearson Educations.

Keraf, A.S. (2010). Etika Lingkungan Hidup. Jakarta: Kompas

Kemendiknas. (2010a). Pengembangan Pendidikan Budaya dan

Karakter Bangsa. Jakarta: Kemendiknas.

Lickona, T. (1992). Educating for Character. New York: BantamBook. 
Lutan, R. (2001). Keniscayaan Pluralitas Budaya Daerah: Analisis Dampak Sistem Nilai Budaya terhadap Eksistensi Bangsa. Bandung: Angkasa.

Muslich, M. (2011). Pendidikan Karakter. Jakarta: Bumi Aksara.

Ridwan, N. A. (2007). "Landasan Keilmuan Kearifan Lokal". Jurnal Studi Islam dan Budaya. Vol.5, (1), 27-38.

Sibarani, R (2012) Kearifan Lokal: Hakikat, Peran, dan Metode Tradisi Lisan. Jakarta: Asosiasi Tradisi Lisan (ATL).

Soedarsono, S. (2008). Membangun Jati Diri Bangsa. Jakarta: PT Elex Media Komputindo.

Soedjatmiko. (1986). Dimensi Manusia dalam Pembangunan Nasional. Yogyakarta: Tiara Wacana.

Tilaar H.A.R (2009). Kekuasaan dan Pendidikan: Manajemen Pendidikan Nasional Dalam Pusaran Kekuasaan. Jakarta: Rineka cipta.

Tilaar H.A.R (2013). Perubahan Sosial dan Pendidikan: Pengantar Pedagogik Transformatif Untuk Indonesia. Jakarta: Rineka cipta.

Tilaar H.A.R (2002). Pendidikan, Kebudayaan, dan Masyarakat Madani Indonesia. Bandung: Rosdakarya.

UU Sisdiknas. (2010). Undang-Undang Sistem Pendidikan Nasional. Bandung: Fokusmedia.

Wibowo, A (2012). Pendidikan Karakter: Strategi Membangun Karakter Bangsa Berperadaban. Yogyakarta: Pustaka Pelajar. 